\title{
Reconstitution of both steps of Saccharomyces cerevisiae splicing with purified spliceosomal components
}

\author{
Zbigniew Warkocki ${ }^{1}$, Peter Odenwälder ${ }^{1}$, Jana Schmitzová ${ }^{1}$, Florian Platzmann ${ }^{2}$, Holger Stark $^{2,3}$, \\ Henning Urlaub ${ }^{4}$, Ralf Ficner ${ }^{5}$, Patrizia Fabrizio ${ }^{1}$ \& Reinhard Lührmann ${ }^{1}$
}

The spliceosome is a ribonucleoprotein machine that removes introns from pre-mRNA in a two-step reaction. To investigate the catalytic steps of splicing, we established an in vitro splicing complementation system. Spliceosomes stalled before step 1 of this process were purified to near-homogeneity from a temperature-sensitive mutant of the RNA helicase Prp2, compositionally defined, and shown to catalyze efficient step 1 when supplemented with recombinant Prp2, Spp2 and Cwc25, thereby demonstrating that Cwc25 has a previously unknown role in promoting step 1. Step 2 catalysis additionally required Prp16, Slu7, Prp18 and Prp22. Our data further suggest that Prp2 facilitates catalytic activation by remodeling the spliceosome, including destabilizing the SF3a and SF3b proteins, likely exposing the branch site before step 1. Remodeling by Prp2 was confirmed by negative stain EM and image processing. This system allows future mechanistic analyses of spliceosome activation and catalysis.

Splicing of pre-mRNA is catalyzed by the spliceosome, which is comprised of the U1, U2, U4-U6 and U5 small nuclear ribonucleoproteins (snRNPs) and additional non-snRNP proteins. During spliceosome assembly, short conserved sequences of the pre-mRNA, including the $5^{\prime}$ and $3^{\prime}$ splice sites (SS) and the branch-site (BS) sequence are recognized sequentially. First, the U1 and U2 snRNPs bind, followed by the U4-U6•U5 tri-snRNP, forming the precatalytic complex B. Subsequent activation of the spliceosome requires rearrangements leading to the displacement of U1 and U4 (ref. 1). The activated spliceosome $\left(\mathrm{B}^{\text {act }}\right)$ undergoes additional rearrangements before step 1 of splicing occurs, but they are still not well understood. During step 1, the BS adenosine attacks the $5^{\prime}$ SS, generating the cleaved $5^{\prime}$ exon and intron $-3^{\prime}$ exon lariat intermediates. The spliceosomal C complex is formed at this time and catalyzes the second step of splicing, during which the intron is excised and the $5^{\prime}$ and $3^{\prime}$ exons are ligated to form mature mRNA ${ }^{2}$.

A complex RNA network involving the spliceosomal small nuclear RNAs (snRNAs) and the pre-mRNA is formed during spliceosome assembly, and the resulting RNA structure is central in catalyzing the first and second steps of splicing ${ }^{3}$. Nonetheless, spliceosome assembly and activation as well as first- and second-step catalysis require the assistance of proteins ${ }^{4}$. The structural dynamics of the spliceosome are facilitated by the action of multiple $\mathrm{DExD} / \mathrm{H}$-box helicases ${ }^{5}$. Among these evolutionarily conserved helicases are Prp2, Prp16 and Prp22, which are essential DEAH-box ATPases required for the first- and second-step reactions ${ }^{6-9}$. Prp2 associates with the $\mathrm{B}^{\text {act }}$ spliceosome, and upon ATP hydrolysis Prp2 promotes a structural rearrangement that transforms $\mathrm{B}^{\text {act }}$ into a catalytically active complex named $\mathrm{B}^{\star}$ (refs. 10,11). However, Prp2 alone is not sufficient for efficient catalysis of step 1, which additionally requires a heat-stable factor of unknown identity ${ }^{10}$. Similarly, Prp16 restructures the $\mathrm{C}$ complex and has been proposed to drive rearrangements required for exon ligation and also to assist with splicing fidelity ${ }^{12,13}$. The Prp16-catalyzed conformational change permits the binding of the step 2 factors Slu7, Prp18 and Prp22 to the spliceosome. With Slu7, Prp18 and Prp22 in place, catalysis of step 2 occurs $^{9,14-19}$.

Proteomic analyses of purified human spliceosomal complexes have revealed that the spliceosome is a protein-rich RNP machine and that there is a substantial exchange of spliceosomal proteins throughout the splicing process, in particular during the transition from $\mathrm{B}$ to $\mathrm{C}$ complex ${ }^{20}$. Recent affinity purification of Saccharomyces cerevisiae spliceosomal complexes that were stalled at defined functional stages show that the yeast spliceosome is much less complex than those of higher eukaryotes ${ }^{11}$. These studies also show that only a handful of proteins are recruited during the transition from $\mathrm{B}^{\text {act }}$ to $\mathrm{C}$ complex, concomitantly with step 1 of splicing; however, the role (if any) of these proteins in splicing remains unclear ${ }^{11}$. To date, the function of the spliceosome has been studied using whole-cell extracts, partially purified components or immunoprecipitated, matrix-bound spliceosomes ${ }^{10,17,21}$. To discern the requirements for both catalytic steps of splicing, we set out to establish an in vitro splicing complementation system that recapitulates both steps of splicing from extensively purified precatalytic spliceosomes of defined composition, supplemented with native and/or recombinant components.

\footnotetext{
${ }^{1}$ Department of Cellular Biochemistry and ${ }^{2} 3 \mathrm{D}$ Electron Cryomicroscopy Group, Max Planck Institute of Biophysical Chemistry, Göttingen, Germany. ${ }^{3}$ Göttingen Center of Molecular Biology, Institute for Microbiology and Genetics, Georg August University Göttingen, Göttingen, Germany. ${ }^{4}$ Bioanalytical Mass Spectrometry Group, Max Planck Institute of Biophysical Chemistry, Göttingen, Germany. ${ }^{5}$ Department for Molecular Structural Biology, Institute for Microbiology and Genetics, Georg August University Göttingen, Göttingen, Germany. Correspondence should be addressed to R.L. (Reinhard.Luehrmann@mpi-bpc.mpg.de) and P.F. (pfabriz1@gwdg.de).
} 
a

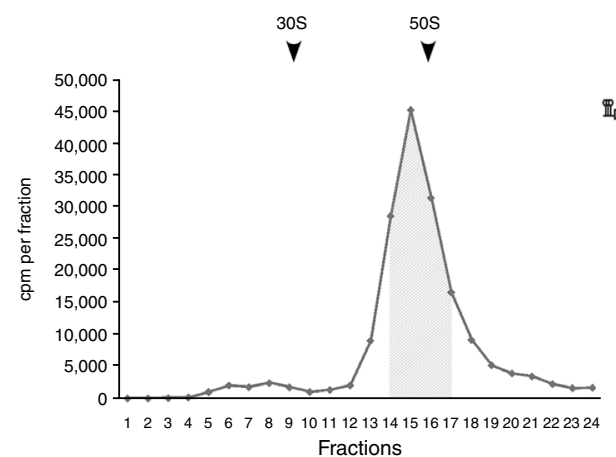

b

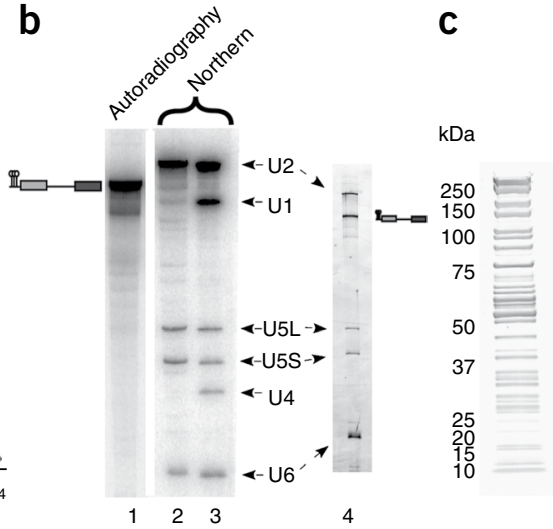

Figure 1 Affinity purification of precatalytic Bact $\Delta$ prp2 spliceosomes. (a) Profile of affinity-purified $B^{\text {act } \Delta p r p 2}$ spliceosomes separated on a $10-30 \%(v / v)$ glycerol gradient. The radioactivity contained in each gradient fraction was determined by Cherenkov counting. Sedimentation coefficients were determined by analyzing the UV absorbance of fractions of a reference gradient containing prokaryotic ribosomal subunits. (b) RNA from gradient fraction 15 was recovered, separated by denaturing PAGE and visualized by autoradiography (lane 1), northern analysis (lane 2) and silver staining (lane 4). Lane 3, total snRNA marker. RNA identities are indicated on the right and left. (c) Protein composition of purified $B^{\text {act }} \triangle$ prp2 spliceosomes. Proteins from four peak fractions (shaded in a) were separated by SDS-PAGE, visualized by staining with Coomassie R-250 and analyzed by MS (Supplementary Table 1).

\section{RESULTS}

\section{Purification of precatalytic Bact $\Delta$ prp2 spliceosomes}

Despite their less complex nature, yeast spliceosomes still comprise more than 80 proteins ${ }^{11}$, and thus the reconstitution of splicing in vitro from individual proteins alone remains prohibitive. As an alternative, we first affinity-purified precatalytic spliceosomes that were stalled just before step 1 of splicing and then complemented them either with total proteins obtained from purified catalytic step 1 spliceosomes (complex C) or with purified recombinant proteins. For this purpose, we performed splicing in vitro with radiolabeled wild-type actin pre-mRNA and heat-inactivated extract derived from the previously described temperature-sensitive Prp2 mutant (prp2-1) (ref. 10). For MS2 affinity purification, three MS2 binding sites were fused to the $5^{\prime}$ end of the actin pre-mRNA (M3-Act). For the preparative isolation of precatalytic spliceosomes, ${ }^{32} \mathrm{P}$-labeled M3-Act pre-mRNA, in complex with MS2-MBP fusion protein, was incubated with heatinactivated extract from prp2-1 cells under splicing conditions ${ }^{10}$.

Affinity purification of spliceosomes was performed under physiological conditions according to the recently established three-step purification procedure ${ }^{11,22,23}$. Purified spliceosomes showed a sedimentation coefficient of $\sim 45 \mathrm{~S}$, migrated as a single peak during glycerol gradient centrifugation (Fig. 1a), and were found, by northern blot analyses and silver staining, to contain nearly equimolar amounts of U2, U5 and U6 snRNA together with unspliced pre-mRNA, but no U1 and U4 snRNA (Fig. 1b, lanes 1-4). Thus, the purified complex is activated, because $\mathrm{U} 1$ and $\mathrm{U} 4$ have been released, but it is stalled before Prp2 action and is thus still precatalytic. We term this spliceosomal complex $B^{\text {act }} \Delta$ prp2 . Proteins isolated from the affinity-purified $\mathrm{B}^{\text {act } \Delta \mathrm{prp} 2}$ complex were separated by SDS-PAGE (Fig. 1c), analyzed by liquid chromatography-coupled tandem MS (LC-MS/MS) and scored by the absolute number of peptides identified. The purified Bact $\Delta$ prp2 complex contains $\sim 45$ proteins. These include all of the U2 snRNP proteins, the U5 proteins Prp8, Brr2 and Snu1 14 and nearly all of the 19 complex (NTC) proteins, as well as a group of proteins named NTC-related (Supplementary Table 1). The NTC-related proteins are homologous to human proteins that either physically interact with
Prp19 or cell division cycle 5-like (CDC5L) in humans or are present with Prp19 in the human 35S U5 snRNP24 (Supplementary Table 1). These include Prp45, Prp46, Cwc15, Bud31, Ecm2 and Cwc2. Consistent with the absence of U1 and U4 snRNAs, complex $B^{\text {act } \Delta p r p 2}$ lacks nearly all U1- and U4-U6specific proteins. However, the U6 snRNAassociated Lsm2-8 proteins are present to some extent. Previous studies suggest that the Lsm proteins dissociate at the time of spliceosome activation ${ }^{25}$. To date, the precise step at which the U6 Lsm2-8 and U4-U6 proteins are destabilized is not known, and it is not clear whether they are released concomitantly or in discrete steps. The U5-specific proteins Prp6 and Dib1, and the proteins specific to the U4-U6•U5 tri-snRNP (Snu66, Spp381, Prp38 and Snu23), are also essentially absent from $B^{\text {act } \Delta \text { prp2 }}$ (Supplementary Table 1). As expected, Prp2 is absent, but some peptides of the Prp2 recruitment factor Spp2 (ref. 26) were identified, indicating that Spp2 binds to $B^{\text {act } \Delta p r p 2}$ in the absence of Prp2. Furthermore, Yju2 (ref. 27), a protein that is required for step 1 but acts after Prp2, is efficiently recruited to the spliceosome in the absence of Prp2 (Supplementary Table 1). Notably, Prp17, one of the step 2 splicing factors, is abundant in the $\mathrm{B}^{\text {act } \Delta \mathrm{prp} 2}$ complex, whereas all other step 2 splicing factors are absent, consistent with recent data that suggest Prp17 may already be involved in step 1 of splicing ${ }^{28}$. All of the proteins mentioned above are well-established splicing factors and were also found in previously purified yeast spliceosomes ${ }^{11,29}$. In addition, purified $\mathrm{B}^{\text {act }} \Delta \mathrm{pr}$ r2 contains a number of proteins, such as ribosomal and RNA polymerase proteins (Supplementary Table 1), that are typical contaminants of isolated yeast spliceosomal complexes at every stage of assembly ${ }^{11}$.

\section{Purified $\mathrm{B}^{\text {act } \Delta \text { prp2 }}$ spliceosomes are active}

To test whether $\mathrm{B}^{\text {act }} \Delta \mathrm{pr} 2 \mathrm{2}$ complexes are suitable for reconstituting the catalytic steps of splicing, we first complemented them with micrococcal nuclease (MN)-digested extract from wild-type yeast cells and incubated the reaction mixture for $60 \mathrm{~min}$ at $23^{\circ} \mathrm{C}$ under splicing conditions. Purified $\mathrm{B}^{\mathrm{act}} \Delta \mathrm{prp} 2$ complex efficiently underwent both steps of splicing in the presence of MN-digested extract (Fig. 2a, lane 3), which is devoid of all snRNAs (Fig. 2b, lane 2), demonstrating that $\mathrm{B}^{\mathrm{act}} \Delta \mathrm{prp} 2$ is a functional intermediate. We recently described the affinity purification and characterization of the protein composition of a yeast spliceosomal C complex that was stalled after catalytic step 1 due to $3^{\prime}$ SS mutation ${ }^{11}$. A comparison of the protein compositions of the stalled C complex and purified $\mathrm{B}^{\text {act } \Delta \mathrm{pr} 2} \mathrm{2}$ reveals that all proteins present in $B^{\text {act }} \Delta$ prp2 are also found in the $C$ complex (see above and Supplementary Table 1). However, the C complex additionally contains Prp2, the step 2 factors Slu7, Prp18, Prp22 and Prp16 (the latter only in small amounts), and the disassembly factors Prp43, Ntr1 and Ntr2, as well as small amounts of two other proteins, Cwc23 and Cwc25 (refs. 11,29). These proteins will henceforth be collectively referred to as C complex-specific proteins. Notably, when purified $\mathrm{B}^{\text {act }} \Delta \mathrm{prp} 2$ was supplemented with an $\sim 15$-fold molar excess of total proteins from purified MN-digested complex C, both steps of splicing were observed (Fig. 2a, lane 4), though at much lower yields compared to the complementation reaction with 


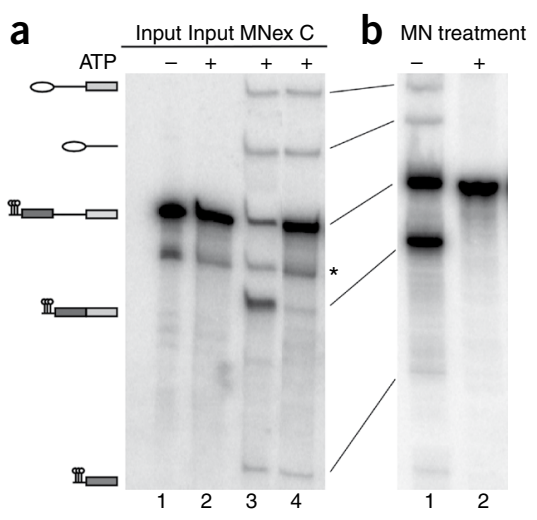

$\mathrm{MN}$-digested total yeast extract. Our data therefore indicate that the $\mathrm{C}$ complex-specific proteins alone are sufficient for catalytic activation of the purified complex $\mathrm{B}^{\text {act } \Delta \mathrm{prp}^{2}}$ and subsequent splicing catalysis.

\section{Cwc25 promotes efficient step 1 catalysis}

We next investigated the requirement of individual $\mathrm{C}$ complexspecific proteins for efficient catalysis of step 1 of splicing by the $\mathrm{B}^{\text {act } \Delta \mathrm{prp} 2}$ complex. First we incubated $\mathrm{B}^{\text {act } \Delta \mathrm{prp} 2}$ with purified recombinant Prp2 and Spp2 (Prp2/Spp2) under splicing conditions for $60 \mathrm{~min}$. A low level of step 1 catalysis was observed at $\sim 300$-fold molar excess of Prp2/Spp2 (Fig. 3a, lane 4), which is strictly dependent on the presence of ATP in the splicing reaction (see below). However, increasing (or lowering) the concentration of $\operatorname{Prp} 2$ or extending the incubation time did not increase the yield of splicing intermediates (data not shown). This suggests that one or more factors aside from $\operatorname{Prp} 2$ and Spp 2 are required for efficient step 1 catalysis. The requirement for Prp2 was highly specific at this step: Prp2 could not be replaced by another recombinant RNA helicase (such as Prp16 or Prp22) (Supplementary Fig. 1). Of the nine C complex-specific proteins described above, Cwc23 and Cwc 25 were of particular interest as no function had yet been assigned to them ${ }^{11}$. We therefore incubated

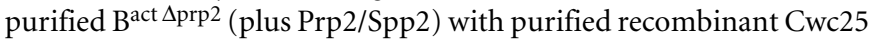
and/or Cwc23 under splicing conditions. The addition of Cwc25, but not Cwc23, increased the yield of splicing intermediates up to $50-60 \%$ of the input pre-mRNA (Fig. 3a, lanes 6 and 7). No splicing intermediates were observed when $\mathrm{B}^{\text {act }} \Delta$ prp$^{2}$ was incubated with Cwc25 in the absence of Prp2/Spp2 (Fig. 3a, lane 5). Correct BS formation was confirmed by primer extension (Supplementary Fig. 2). In sum, these data show that Cwc 25 is required for efficient catalysis of step 1 of splicing.

Figure 3 Reconstitution of both steps of $S$. cerevisiae pre-mRNA splicing with recombinant proteins. (a) $B^{\text {act }} \Delta$ prp2 spliceosomes (Input) incubated without (lane 1) or with ATP alone (lane 2) or plus MN-digested extract (MNex, lane 3), recombinant Prp2 and Spp2 (lane 4), Cwc25 (lane 5), Prp2/Spp2 and Cwc25 (lane 6) or Prp2/Spp2 and Cwc23 (Iane 7). (b) Bact $\Delta$ prp2 spliceosomes supplemented with Prp2/Spp2 and Cwc25 that was previously incubated at the temperatures indicated (lanes 3-5), or with Spp2, Cwc25 and Prp2 that was previously incubated at the temperature indicated (lane 6). (c) Purified Bact $\Delta$ prp2 spliceosomes incubated with ATP alone (lane 1) or ATP plus MN-digested extract (MNex, lane 2), Prp2/Spp2 and Cwc25 (lane 3), Prp2/Spp2, Cwc25 and MN-digested C complex (lane 4) plus Prp16 (lane 5) or Cwc23 (lane 6). (d) Purified Bact $\Delta$ prp2 spliceosomes incubated with ATP plus Prp2/Spp2/ Cwc25 and Prp16 alone (lane 4) and plus Slu7 (lane 5) or with Prp2/ Spp2/Cwc25/Prp16/Slu7 plus Cwc23 (lane 6) or Prp18 and Prp22 (lane 7) or with Prp2/Spp2/Cwc25/Prp16 and MN-digested C complex (lane 8). Lanes 1-3 are as in panels (b,c). Splicing was analyzed as in Figure 2. Asterisks, uncharacterized pre-mRNA-derived band.
Figure 2 Reconstitution of both steps of $S$. cerevisiae pre-mRNA splicing with native proteins. (a) Precatalytic Bact $\Delta$ prp2 spliceosomes (Input) incubated without ATP (lane 1) or with ATP (lane 2) or plus $\mathrm{MN}$-digested extract (MNex, lane 3 ) or MN-digested purified C complex (lane 4). Splicing was analyzed by denaturing PAGE and visualized by autoradiography. (b) Control splicing reactions using whole-cell extract before (-) and after (+) digestion with MN. Pre-mRNA and splicing intermediates are indicated on the left, from the top: lariat intron-3' exon, lariat intron, pre-mRNA, mRNA, 5' exon. Asterisk, uncharacterized pre-mRNA-derived band.

\section{Cwc25 is a heat-stable step 1 factor}

Previously it was shown that a partially purified protein fraction required for step 1 of splicing in yeast contained one or more thermostable splicing factors ${ }^{10}$. Cwc 25 contains a short coiled-coil motif and has a high ratio of glutamate and lysine residues versus histidine and glutamine residues, properties typical of thermotolerant proteins ${ }^{30-32}$. We therefore incubated recombinant Cwc25 at increasing temperatures for $5 \mathrm{~min}$ and tested whether it retained its step 1 promoting activity. Heating Cwc25 even to $100^{\circ} \mathrm{C}$ did not decrease its activity (Fig. 3b, lane 5). In contrast, incubation of Prp2 at $50{ }^{\circ} \mathrm{C}$ for $5 \mathrm{~min}$ completely abolished splicing activity (Fig. $\mathbf{3 b}$, lane 6). Thus, these data show that Cwc25 is a heat-stable step 1 splicing factor and suggest further that Cwc25 is the heat-stable protein previously called "HP activity" 10 .

\section{Reconstitution of step 2 of splicing}

In Figure 2 we show that complementation of purified complex $B^{\text {act }}$ $\Delta$ prp2 with MN-digested, purified complex C supports low levels of both catalytic steps of splicing. The marked increase in step 1 that we observed after adding an excess of Cwc25 (Fig. 3) suggests that

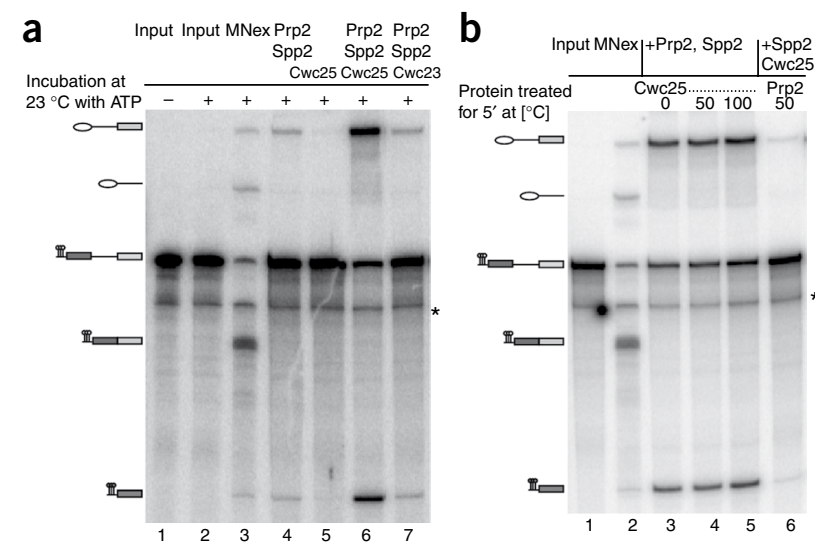

C

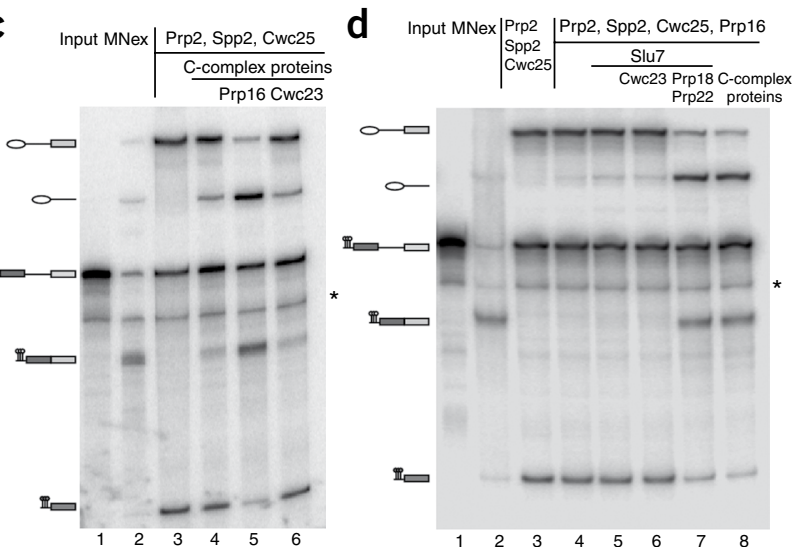



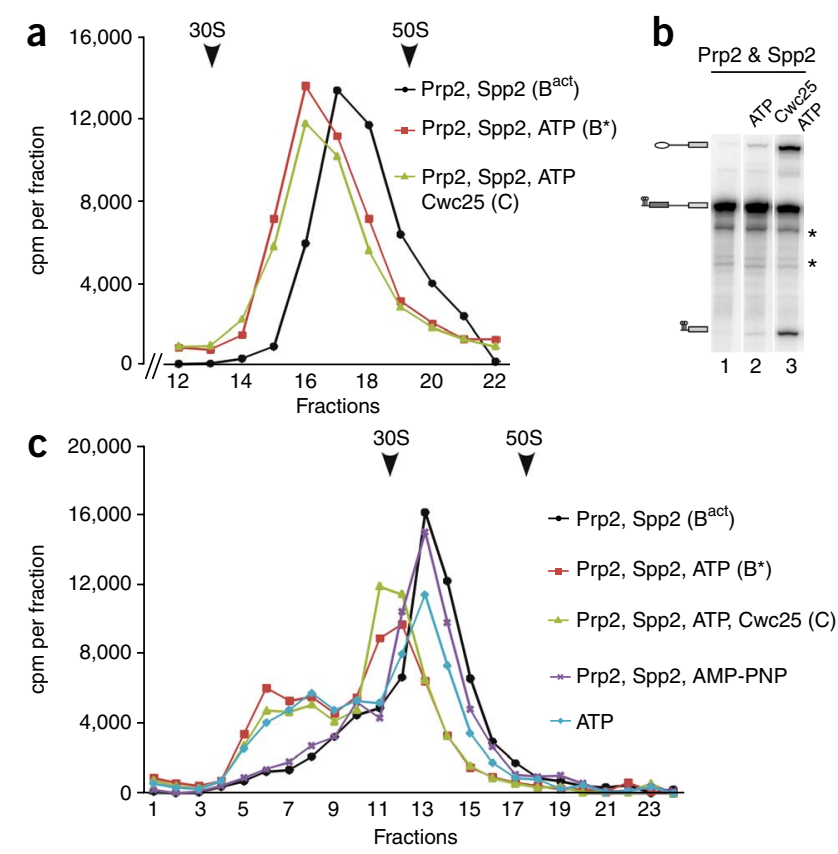

one reason for the observed low levels of splicing catalysis (Fig. 2) is the limiting amount of Cwc25 in the purified C complex. Indeed, only a few peptides of Cwc25 are detected by MS analysis ${ }^{11}$. For comparison, Yju2 was represented by five-fold more peptides ${ }^{11}$. Of the known step 2 splicing factors, Prp16 is also underrepresented in the purified $\mathrm{C}$ complex and may thus also be limiting for efficient mRNA production by complex $\mathrm{B}^{\text {act }} \Delta \mathrm{prp}^{2}$ (ref. 11 ). To investigate this idea, we complemented a mixture of purified $\mathrm{B}^{\text {act }} \Delta$ prp2 and MN-digested complex C with recombinant Prp2, Spp2, Cwc25 and either Prp16 or Cwc23. In the absence of recombinant Prp16, only efficient step 1 catalysis is observed, together with a low level of mRNA production (Fig. 3c, lane 4). In the presence of recombinant Prp16, but not Cwc23, exon ligation was as efficient as that observed when $\mathrm{B}^{\text {act }} \Delta$ prp2 complexes were supplemented with $\mathrm{MN}$-digested splicing extract (Fig. 3c, lanes 5 and 6). This experiment shows that Prp16 is indeed the limiting step 2 factor in the $\mathrm{C}$ complex protein mixture, whereas all other factors required for step 2 are present in sufficient amounts. This in turn indicates that all of the proteins required to promote efficient catalysis of both steps of splicing have been identified.

As additional supporting evidence, we complemented the purified $\mathrm{B}^{\text {act }} \Delta$ prp2 spliceosome with ATP and various combinations of recombinant Prp2, Spp2, Cwc25, Prp16, Slu7, Prp18 and Prp22 or Cwc23. In the presence of Prp16 or Prp16 and Slu7, only efficient step 1 catalysis was observed (Fig. 3c, lanes 4 and 5). Efficient step 2 was detected only when Prp18 and Prp22, but not Cwc23, were added in addition to Prp16/Slu7 (lanes 6 and 7). Correct splice junctions in the mRNA product were determined by sequencing analysis of RT-PCR-generated fragments (data not shown). Thus, this demonstrates that we have identified all of the proteins required to promote efficient catalysis of step 2.

Figure 5 EM images of yeast spliceosomes before and after catalytic activation by Prp2. (a,b) Typical raw images of spliceosomes before (a) and after (b) catalytic activation. (c, d) Typical class averages of spliceosomes before (c) and after (d) catalytic activation by Prp2. In $\mathbf{c}$ and $\mathbf{d}$ the three major views found in the respective datasets are shown. Scale bar, $20 \mathrm{~nm}$.
Figure 4 Catalytic activation of the spliceosome by Prp2. (a) Profiles of affinity-purified $B^{\text {act }} \Delta$ prp2 spliceosomes separated on a glycerol gradient containing $75 \mathrm{mM}$ potassium chloride after incubation with Prp2/Spp2 (45S Bact), Prp2/Spp2/ATP (40S B*) or Prp2/Spp2/Cwc25/ATP (40S C). The radioactivity contained in each gradient fraction was determined by Cherenkov counting. Sedimentation coefficients were determined as described in Figure 1. (b) RNA from gradient peak fractions was separated by denaturing PAGE and visualized by autoradiography. Proteins were recovered as described in Online Methods, separated by SDS-PAGE and analyzed by MS (Supplementary Table 2). RNA identities are described in Figure 2. (c) Profiles of affinity-purified Bact $\Delta$ prp2 spliceosomes separated on a glycerol gradient containing $500 \mathrm{mM}$ potassium chloride after incubation with Prp2/Spp2 (35S B ${ }^{\text {act }}$ ), Prp2/Spp2/ATP (28S B*) or Prp2/Spp2/Cwc25/ATP (28S C) or Prp2/Spp2/AMP-PNP (35S Bact) or solely ATP (35S Bact $\Delta p r p 2)$. Proteins from gradient peak fractions were analyzed by MS (Supplementary Table 2 and data not shown).

\section{Spliceosome remodeling by Prp2}

ATP hydrolysis by Prp2 (Supplementary Fig. 3a,b) promotes a poorly understood remodeling event that transforms $\mathrm{B}^{\text {act }}$ into the catalytically active $\mathrm{B}^{\star}$ complex. The possibility of recapitulating the catalytic activation of the purified $\mathrm{B}^{\text {act } \Delta \text { prp } 2}$ complex by complementation with Prp2 allowed us to investigate the effect of Prp2 activity on spliceosome structure in more detail. We first analyzed the effect of Prp2 on the sedimentation behavior of purified $\mathrm{B}^{\text {act }} \Delta \mathrm{prp}^{2}$ complex in glycerol gradients containing $75 \mathrm{mM}$ potassium chloride. Incubation of purified complex Bact $\Delta$ prp2 with Prp2/Spp2 and ATP leads to a significant shift in sedimentation coefficient (Fig. 4a), such that the $45 \mathrm{~S} \mathrm{Bct}^{\text {act }}$ is almost quantitatively ( $\sim 80-90 \%)$ converted into a slower-migrating $40 \mathrm{~S} \mathrm{~B}^{\star}$ complex. The shift was not observed in the presence of solely Prp2/Spp2, ATP, or Prp2/Spp2 and the nonhydrolyzable ATP ana$\log$ (AMP-PNP) (data not shown and Supplementary Fig. 3c,d). Although incubation of $\mathrm{B}^{\text {act } \Delta \mathrm{prp}^{2}}$ with Prp2/ATP and Cwc25 yields $\geq 50 \%$ of catalytic step 1 C complex (Fig. $4 \mathbf{a}, \mathbf{b}$ ), no additional shift in sedimentation coefficient was detected when compared to the catalytically activated $B^{\star}$ complex (Fig. $4 \mathbf{a}$ ). RNA analysis of the respective peak fractions from the gradients reveals, as expected, low and high levels of intermediates after incubation of the spliceosome with
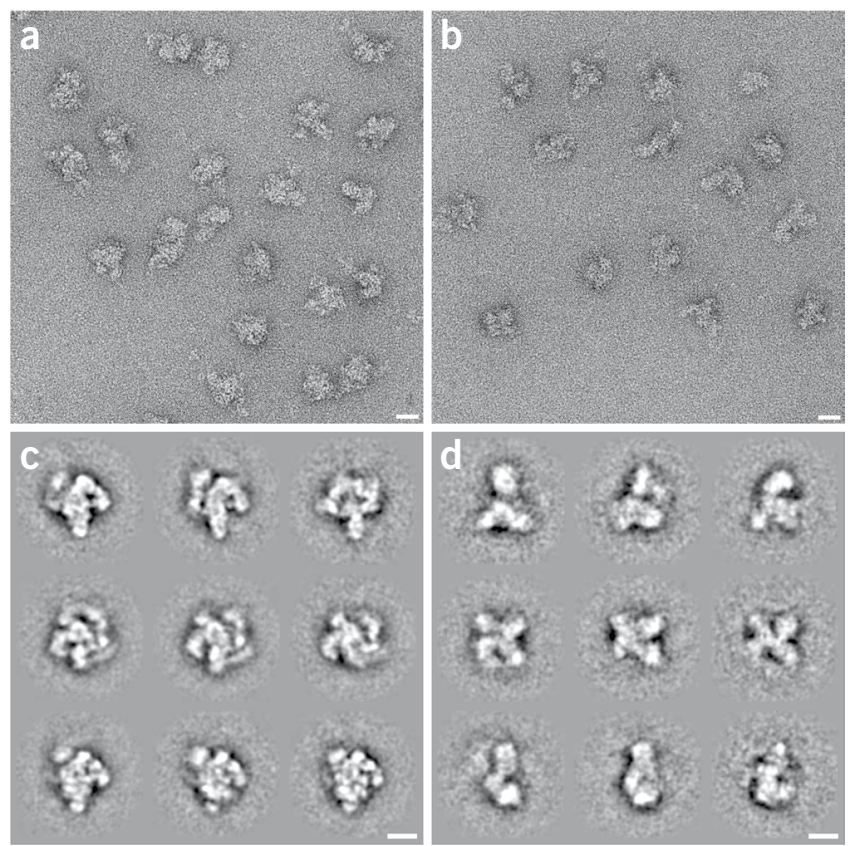


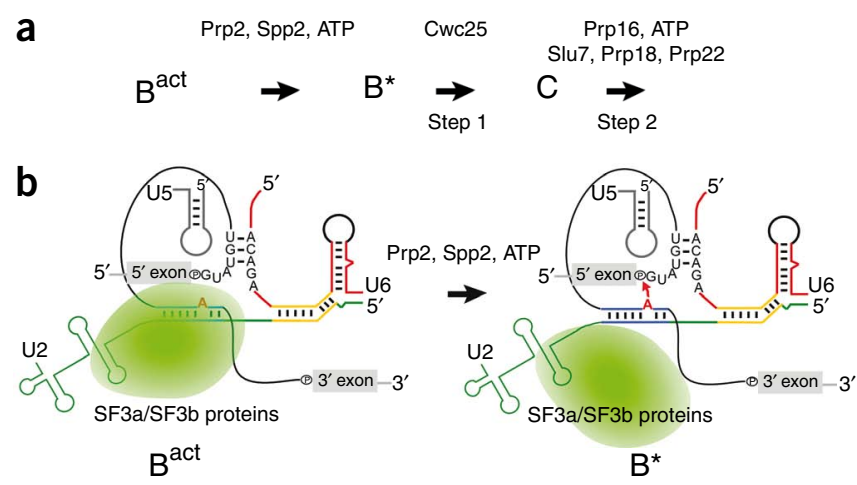

Figure 6 Model for the catalytic activation of the spliceosome by Prp2 before Cwc25-promoted step 1. (a) The transition from an activated (Bact) to a catalytically activated $\left(B^{*}\right)$ spliceosome requires the activity of Prp2 and Spp2 and the presence of ATP; the formation of a step 1 spliceosome (C) is then promoted by Cwc25. Subsequently, C catalyzes step 2 upon addition of Prp16, ATP and Slu7, Prp18 and Prp22. (b) Network of RNA interactions in the activated (left, $B^{\text {act }}$ ) and catalytically activated spliceosome (right, $B^{*}$ ) with critical base-pairing interactions highlighted in color. During catalytic activation of the spliceosome, the U2 SF3a and SF3b proteins are destabilized by Prp2/ATP such that the BS adenosine becomes available for a nucleophile attack at the 5' SS (red arrow).

Prp2/Spp2/ATP or Prp2/Spp2/ATP plus Cwc25, respectively (Fig. 4b, lanes 2 and 3). These results indicate that Prp2-dependent ATPase activity leads to a structural rearrangement of the spliceosome during its catalytic activation, as evidenced by the reduced sedimentation behavior of the catalytically activated $\mathrm{B}^{\star}$ compared to $\mathrm{B}^{\text {act }}$.

The reduced sedimentation coefficient of the $\mathrm{B}^{\star}$ complex could be due to the loss of spliceosomal proteins and/or rearrangements in protein-protein or protein-RNA interactions upon Prp2-mediated activation. We therefore compared the protein composition of the $45 \mathrm{~S}$ $\mathrm{B}^{\text {act }}$ with that of the catalytically activated $40 \mathrm{~S} \mathrm{~B}^{\star}$ complex (Fig. 4a). MS analyses of the peak fractions (Supplementary Table 2) show that there is essentially no difference in the protein composition of the two complexes. However, we consistently observed a decrease in the number of peptides for the retention and splicing (RES) complex, Cwc24 and Cwc27, in the $40 \mathrm{~S} \mathrm{~B}^{\star}$ complex (Supplementary Table 2). To investigate whether protein-protein or protein-RNA interactions in $\mathrm{B}^{*}$ are destabilized, we compared the salt sensitivity of the association of spliceosomal proteins in $\mathrm{B}^{\star}$ and $\mathrm{B}^{\text {act }}$. For this purpose, purified $\mathrm{B}^{\text {act }} \Delta$ prp2 complexes were incubated under splicing conditions either with Prp2/Spp2, Prp2/Spp2/ATP, Prp2/Spp2/Cwc25/ATP, Prp2/Spp2/AMP-PNP or ATP alone, and then subjected to glycerol gradient centrifugation in $500 \mathrm{mM}$ potassium chloride. Under these conditions, the majority of $\mathrm{B}^{\text {act } \Delta \text { prp2 }}$ complexes (plus Prp2/Spp2) had a sedimentation coefficient of $\sim 35 \mathrm{~S}$ (Fig. 4c). A similar sedimentation behavior was observed for $\mathrm{B}^{\text {act } \Delta \text { prp2 }}$ plus Prp2/Spp2/AMP-PNP. After incubation of $\mathrm{B}^{\text {act }} \Delta \mathrm{prp} 2$ with ATP alone, about two-thirds of the $\mathrm{B}^{\text {act } \Delta \mathrm{prp} 2}$ complex still migrated at $\sim 35 \mathrm{~S}$, whereas one-third migrated with a broad range of sedimentation coefficients between $8 \mathrm{~S}$ and $20 \mathrm{~S}$. However, when $\mathrm{B}^{\text {act } \Delta \text { prp2 }}$ were incubated with Prp2/Spp2/ATP, spliceosomes no longer peaked at $\sim 35 \mathrm{~S}$; rather, most migrated with a sedimentation coefficient of $\sim 28 \mathrm{~S}$, with a fraction showing coefficients of 8-20S (Fig. 4c). Note that the latter fraction is quantitatively

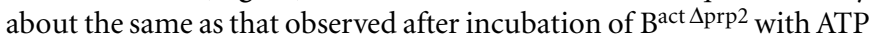
alone (analyses of RNA indicate the presence of intact pre-mRNA and snRNA, data not shown). Catalytic step 1 spliceosomes (Prp2/ Spp2/Cwc25/ATP) therefore show the same sedimentation behavior as catalytically activated spliceosomes $\left(\mathrm{B}^{*}\right)($ Fig. $4 \mathrm{c})$.
We next investigated the protein composition of the various spliceosomes after glycerol gradient centrifugation in $500 \mathrm{mM}$ potassium chloride, analyzing the peak fractions of the gradients for the activated $35 \mathrm{~S}$ and catalytically activated $28 \mathrm{~S}$ complexes. Compared to $45 \mathrm{~S} \mathrm{~B}^{\text {act }}$ spliceosomes subjected to $75 \mathrm{mM}$ potassium chloride (Supplementary Table 2), activated $35 \mathrm{~S} \mathrm{~B}^{\text {act }}$ spliceosomes primarily lacked Yju2, Cwc21, Cwc27 and Prp17, while U5 and NTC proteins, and most importantly all of the U2-associated SF3a and SF3b proteins, remained strongly bound, with the exception of the U2specific proteins Lea1 and Msl1, which were substantially reduced. Of the U5 proteins, only Brr2 was reduced (Supplementary Table 2). MS analysis shows that the same proteins were also absent from the $28 \mathrm{~S}$ catalytically activated $\mathrm{B}^{\star}$ complex. However, in marked contrast to the $35 \mathrm{~S} \mathrm{~B}^{\text {act }}$ complex, there was a significant reduction in the $\mathrm{U} 2 \mathrm{SF} 3 \mathrm{a}$ and SF3b proteins in the $28 \mathrm{~S} \mathrm{~B}^{\star}$ complex. Likewise, the RES-complex proteins were also essentially absent (Supplementary Table 2). MS analysis shows that the same proteins were also absent from the $28 \mathrm{~S}$ step $1 \mathrm{C}$ complex (data not shown). These data indicate that ATP hydrolysis by Prp2 facilitates the destabilization of $\mathrm{U} 2$ proteins during the conversion of $\mathrm{B}^{\text {act }}$ to $\mathrm{B}^{\star}$ complex, and thus that a significant reorganization occurs before the Cwc25-promoted catalysis of step 1 .

\section{Spliceosome remodeling visualized by EM}

We also studied the Prp2-mediated remodeling of the spliceosome at a structural level by EM and image analysis. A major remodeling event should result in a different morphology of the imaged spliceosomes. About 7,000 images of negatively stained spliceosomes before (Fig. 5a) and after catalytic activation by $\operatorname{Prp} 2$ (Fig. 5b) were subjected to reference-free image analysis at the two-dimensional (2D) level (Fig. 5c,d). We obtained stable 2D class averages after several rounds of image alignment ${ }^{33}$, multivariate statistical analysis and classification $^{34}$. The distribution of views of the spliceosome changed considerably after the catalytic activation step, suggesting that there is indeed a significant change in the structure and/or conformation of the spliceosome upon catalytic activation (details of the distributions and the choice of reference images are given in Supplementary Fig. 4). The EM analysis suggests that catalytically activated spliceosomes were not present (or at least not detectable) before catalytic activation by Prp2, whereas they represented the greater part of the population after catalytic activation. However, some $B^{\text {act }}$ images were still seen after catalytic activation. This is consistent with our biochemical data, which indicate a conversion rate of $\sim 80-90 \%$ (see Fig. 4 a). On this basis, we expect the changes in spliceosome structure upon catalytic activation to be substantial, as minor changes in structure would not result in such obvious differences as those observed here.

\section{DISCUSSION}

Here we have established a system that allows us to reconstitute both catalytic steps of yeast pre-mRNA splicing from purified, biochemically defined components. This was achieved by complementing purified spliceosomes ( $\mathrm{B}^{\text {act } \Delta \mathrm{prp}^{2}}$ ), which were stalled before the catalytic activation step mediated by the RNA helicase Prp2, with native proteins from independently purified yeast C-complex spliceosomes and/ or purified recombinant splicing factors. We show that efficient catalysis of step 1 by the purified $\mathrm{B}^{\text {act }} \Delta \mathrm{prp}^{2}$ complex requires Prp2, Spp2 and Cwc25 (Fig. 6a). Thus, Cwc25, whose function had been unknown, is a step 1 splicing factor that is evolutionarily highly conserved among higher and lower eukaryotes. We show that Cwc25 is a heat-stable protein representing the "HP activity" previously shown to be required for splicing ${ }^{10}$. While this paper was under review, 
a report was published that analyzed the function of Cwc25 in an in vitro depletion and reconstitution system ${ }^{35}$. These data suggest that Cwc25 is not sufficient to replace the function of HP and that another heat-resistant factor (HP-X) is involved. This postulated additional HP-X activity ${ }^{35}$ appears to be already integrated in our $\mathrm{B}^{\text {act } \Delta \text { prp2 }}$ spliceosome.

What could be the molecular basis of the dramatic stimulation of step 1 by Cwc25? Cwc25 could interact with one or more proteins in the neighborhood of the catalytic center and render its microenvironment favorable for step 1 . In the absence of Cwc25, the catalytically activated spliceosome might in principle be capable of catalyzing step 1 , but it could shift back and forth between an inactive and active conformation. A recent report showed that the requirement of Cwc25 and HP-X for step 1 could be partially bypassed by incubation of matrix-bound spliceosomes in the presence of $\mathrm{Mn}^{2+}$ (refs. 21,35). Thus, Cwc25 binding might shift this equilibrium toward step 1, suggesting that it assists in proper $5^{\prime}$ SS and BS configuration to promote step 1 under physiological splicing conditions (such as in the presence of $\mathrm{Mg}^{2+}$ ). Finally, we cannot exclude an even more direct role for Cwc25 in step 1. Our reconstitution system should allow us to answer these questions using biochemical and biophysical methods.

Although the essential role of Prp2 in the catalytic activation of the spliceosome was established several years ago, its mechanism of action remained enigmatic. Here we show by EM that ATP hydrolysis by $\operatorname{Prp} 2$ has a significant effect on the structure of the spliceosome as a prerequisite for its catalytic activation and that this remodeling takes place without the loss of bound proteins. ATP hydrolysis by Prp2 also affects the stability of the interaction of the U2 snRNP SF3a and SF3b proteins with the spliceosome. In precatalytic human spliceosomes, several of the SF3a and SF3b proteins interact with pre-mRNA sequences upstream and downstream of the BS and thereby stabilize binding of the U2 snRNP to the spliceosome ${ }^{36}$. It is also likely that these evolutionarily conserved U2 proteins play a similar role in the yeast spliceosome. Thus, their destabilization by Prp2/ATP would indicate that the structure of the spliceosome near the BS is remodeled such that the BS adenosine becomes available for a nucleophile attack at the $5^{\prime}$ SS phosphodiester bond (Fig. 6b). In purified yeast and human spliceosomal $\mathrm{C}$ complexes, SF3a and SF3b proteins are underrepresented ${ }^{11,23}$, suggesting that they may dissociate concomitantly either with step 1 or with the subsequent Prp16-mediated remodeling of the spliceosome ${ }^{13}$. Previous work indicates that, in yeast, step 2 of splicing can proceed in the absence of U2-BS sequence base-pairing ${ }^{37}$. Thus, whereas SF3a and SF3b are essential early in the splicing reaction, they may not be required after the first and second catalytic steps. An open question is how Prp2/ATP facilitates destabilization of SF3a and SF3b. An interesting possibility could be that Prp2/ATP may directly or indirectly mediate a conformational change in the U2 RNA structure, which in turn could result in the remodeling of the catalytic spliceosome's RNP core. Our in vitro reconstitution system, in combination with biophysical methods, paves the way to addressing this question.

Extensively purified step 1 spliceosomes undergo step 2 catalysis when supplemented with native proteins derived from complex $\mathrm{C}$ plus recombinant Prp16. We show that efficient step 2 catalysis requires the addition of recombinant step 2 factors alone to step 1 spliceosomes (Fig. 6a). This shows that all of the proteins necessary for both steps of splicing must consist of these exogenously added proteins, in addition to the core components of the $\mathrm{B}^{\text {act } \Delta \text { prp } 2}$ spliceosome. In conclusion, the system described here offers new possibilities for future functional and mechanistic analyses of the first and second steps of splicing, as well as biophysical and ultrastructural studies of spliceosomal dynamics.

\section{METHODS}

Methods and any associated references are available in the online version of the paper at http://www.nature.com/nsmb/.

Note: Supplementary information is available on the Nature Structural \& Molecular Biology website.

\section{ACKNOWLEDGMENTS}

We thank M. Raabe, U. Plessmann and J. Lehne for their help in MS analysis; R.-J. Lin (Beckman Research Institute) for providing the yeast mutant prp2-1; and R. Rauhut and C.L. Will for helpful comments on the manuscript. This work was supported by grants from the European Commission (EURASNET-518238) and the Ernst Jung Stiftung to R.L., a fellowship provided by the Stiftung StipendienFonds des Verbandes der Chemischen Industrie to Z.W., by the Stiftung der deutschen Wirtschaft to P.O., and a Young Investigator Programme grant from EURASNET to H.U.

\section{AUTHOR CONTRIBUTIONS}

Z.W., P.O., J.S., F.P., H.S., R.F., P.F. and R.L. designed experiments; Z.W., P.O., J.S. and F.P. performed the experiments; Z.W., P.F. and R.L. analyzed the data; F.P. and H.S. analyzed the EM data; H.U. analyzed the MS data; Z.W., J.S., H.S., P.F. and R.L. wrote the paper.

Published online at http://www.nature.com/nsmb/.

Reprints and permissions information is available online at http://npg.nature.com/ reprintsandpermissions/.

1. Will, C.L. \& Lührmann, R. Spliceosome structure and function. in RNA World (eds Gesteland, R.F., Cech, T.R. \& Atkins, J.F.) 369-400 (Cold Spring Harbor Laboratory Press, Cold Spring Harbor, New York, 2006).

2. Staley, J.P. \& Guthrie, C. Mechanical devices of the spliceosome: motors, clocks, springs, and things. Cel/ 92, 315-326 (1998).

3. Nilsen, T.W. RNA-RNA interactions in nuclear pre-mRNA splicing. in RNA Structure and Function (eds. Grundber-Manago, M., \& Simons, R.W.) 279-307 (Cold Spring Harbor Laboratory Press, Cold Spring Harbor, New York, 1998).

4. Nilsen, T.W. The spliceosome: the most complex macromolecular machine in the cell? Bioessays 25, 1147-1149 (2003).

5. Pyle, A.M. Translocation and unwinding mechanisms of RNA and DNA helicases. Annu. Rev. Biophys. 37, 317-336 (2008).

6. Schwer, B. \& Guthrie, C. PRP16 is an RNA-dependent ATPase that interacts transiently with the spliceosome. Nature 349, 494-499 (1991).

7. Teigelkamp, S., McGarvey, M., Plumpton, M. \& Beggs, J.D. The splicing factor PRP2, a putative RNA helicase, interacts directly with pre-mRNA. EMBO J. 13 888-897 (1994).

8. King, D.S. \& Beggs, J.D. Interactions of PRP2 protein with pre-mRNA splicing complexes in Saccharomyces cerevisiae. Nucleic Acids Res. 18, 6559-6564 (1990).

9. Schwer, B. \& Gross, C.H. Prp22, a DExH-box RNA helicase, plays two distinct roles in yeast pre-mRNA splicing. EMBO J. 17, 2086-2094 (1998).

10. Kim, S.H. \& Lin, R.J. Spliceosome activation by PRP2 ATPase prior to the first transesterification reaction of pre-mRNA splicing. Mol. Cell. Biol. 16, 6810-6819 (1996).

11. Fabrizio, P. et al. The evolutionarily conserved core design of the catalytic activation step of the yeast spliceosome. Mol. Cell (in the press).

12. Burgess, S.M. \& Guthrie, C. A mechanism to enhance mRNA splicing fidelity: the RNA-dependent ATPase Prp16 governs usage of a discard pathway for aberrant lariat intermediates. Cell 73, 1377-1391 (1993).

13. Mefford, M.A. \& Staley, J.P. Evidence that U2/U6 helix I promotes both catalytic steps of pre-mRNA splicing and rearranges in between these steps. RNA 15, 1386-1397 (2009).

14. Vijayraghavan, U. \& Abelson, J. PRP18, a protein required for the second reaction in pre-mRNA splicing. Mol. Cell. Biol. 10, 324-332 (1990).

15. Horowitz, D.S. \& Abelson, J. Stages in the second reaction of pre-mRNA splicing: the final step is ATP independent. Genes Dev. 7, 320-329 (1993).

16. Umen, J.G. \& Guthrie, C. The second catalytic step of pre-mRNA splicing. RNA 1 , 869-885 (1995).

17. Ansari, A. \& Schwer, B. SLU7 and a novel activity, SSF1, act during the PRP16-dependent step of yeast pre-mRNA splicing. EMBO J. 14, 4001-4009 (1995).

18. Brys, A. \& Schwer, B. Requirement for SLU7 in yeast pre-mRNA splicing is dictated by the distance between the branchpoint and the $3^{\prime}$ splice site. RNA 2, 707-717 (1996). 
19. James, S.A., Turner, W. \& Schwer, B. How Slu7 and Prp18 cooperate in the second step of yeast pre-mRNA splicing. RNA 8, 1068-1077 (2002).

20. Wahl, M.C., Will, C.L. \& Lührmann, R. The spliceosome: design principles of a dynamic RNP machine. Cell 136, 701-718 (2009).

21. Tseng, C.K. \& Cheng, S.C. Both catalytic steps of nuclear pre-mRNA splicing are reversible. Science 320, 1782-1784 (2008).

22. Deckert, J. et al. Protein composition and electron microscopy structure of affinitypurified human spliceosomal B complexes isolated under physiological conditions. Mol. Cell. Biol. 26, 5528-5543 (2006).

23. Bessonov, S., Anokhina, M., Will, C.L., Urlaub, H. \& Lührmann, R. Isolation of an active step I spliceosome and composition of its RNP core. Nature 452, 846-850 (2008).

24. Makarov, E.M. et al. Small nuclear ribonucleoprotein remodeling during catalytic activation of the spliceosome. Science 298, 2205-2208 (2002).

25. Chan, S.P., Kao, D.I., Tsai, W.Y. \& Cheng, S.C. The Prp19p-associated complex in spliceosome activation. Science 302, 279-282 (2003).

26. Roy, J., Kim, K., Maddock, J.R., Anthony, J.G. \& Woolford, J.L. Jr. The final stages of spliceosome maturation require Spp2p that can interact with the DEAH box protein Prp2p and promote step 1 of splicing. RNA 1, 375-390 (1995).

27. Liu, Y.C., Chen, H.C., Wu, N.Y. \& Cheng, S.C. A novel splicing factor, Yju2, is associated with NTC and acts after Prp2 in promoting the first catalytic reaction of pre-mRNA splicing. Mol. Cell. Biol. 27, 5403-5413 (2007).
28. Sapra, A.K., Khandelia, P. \& Vijayraghavan, U. The splicing factor Prp17 interacts with the U2, U5 and U6 snRNPs and associates with the spliceosome pre- and post-catalysis. Biochem. J. 416, 365-374 (2008).

29. Ohi, M.D. et al. Proteomics analysis reveals stable multiprotein complexes in both fission and budding yeasts containing Myb-related Cdc5p/Cef1p, novel pre-mRNA splicing factors, and snRNAs. Mol. Cell. Biol. 22, 2011-2024 (2002).

30. Burkhard, P., Stetefeld, J. \& Strelkov, S.V. Coiled coils: a highly versatile protein folding motif. Trends Cell Biol. 11, 82-88 (2001).

31. Farias, S.T. \& Bonato, M.C. Preferred amino acids and thermostability. Genet. Mol Res. 2, 383-393 (2003).

32. Farias, S.T., van der Linden, M.G., Rego, T.G., Araujo, D.A. \& Bonato, M.C. Thermosearch: lifestyle and thermostability analysis. In Silico Biol. 4, 377-380 (2004).

33. Sander, B., Golas, M.M. \& Stark, H. Corrim-based alignment for improved speed in single-particle image processing. J. Struct. Biol. 143, 219-228 (2003).

34. van Heel, M. \& Frank, J. Use of multivariate statistics in analysing the images of biological macromolecules. Ultramicroscopy 6, 187-194 (1981).

35. Chiu, Y.F. et al. Cwc25 is a novel splicing factor required after Prp2 and Yju2 to facilitate the first catalytic reaction. Mol. Cell. Biol. 29, 5671-5678 (2009).

36. Gozani, O., Potashkin, J. \& Reed, R. A potential role for U2AF-SAP 155 interactions in recruiting U2 snRNP to the branch site. Mol. Cell. Biol. 18, $4752-4760$ (1998).

37. Smith, D.J., Query, C.C. \& Konarska, M.M. trans-splicing to spliceosomal U2 snRNA suggests disruption of branch site-U2 pairing during pre-mRNA splicing. Mol. Cell 26, 883-890 (2007). 


\section{ONLINE METHODS}

In vitro splicing and purification of $\mathrm{B}^{\text {act }} \Delta \mathrm{prp}^{2}$ spliceosomes. Extract was prepared from the yeast strain 3.2.AID (alpha, prp2-1, ade2, his3, lys2-801, ura3, carrying a G360D mutation in Prp2) (ref. 38). Yeast was grown at $25^{\circ} \mathrm{C}$ to an $\mathrm{OD}_{600}$ of 4-7 and the extract was heat-inactivated for $30 \mathrm{~min}$ at $35^{\circ} \mathrm{C}$ before in vitro splicing reactions. Splicing reactions $(1-72 \mathrm{ml})$ were incubated for $30-40 \mathrm{~min}$ at $23^{\circ} \mathrm{C}$ with $1.8-2 \mathrm{nM}$ M3-Act wild-type pre-mRNA. The complexes were purified using a three-step procedure essentially as previously described ${ }^{11}$ with the following changes; the first centrifugation was carried out for $14 \mathrm{~h}$ at 98,264 $g$ and fractions $15-20$ were routinely taken for affinity purification.

Splicing reconstitution assay. $\mathrm{B}^{\text {act }} \Delta \mathrm{prp} 2$ spliceosomes from peak fraction(s) ( 10 or $25 \mathrm{fmol}$, final concentration $0.25 \mathrm{nM}$ ) were combined with RNasin (Promega, 0.15-0.2 $\left.\mathrm{U} \mathrm{\mu l}^{-1}\right)$, recombinant proteins $(0.7-7 \mathrm{pmol}$, final concentration $20-70 \mathrm{nM}$ ) (Supplementary Fig. 5) and a mix containing $40 \mathrm{mM}$ potassium phosphate buffer, pH 7.3, $1.5 \mathrm{mM}$ magnesium chloride, $0.2 \mathrm{mM}$ EDTA, 5\% (v/v) glycerol to a final volume of $90 \mu \mathrm{l}$ or $36 \mu \mathrm{l}$. Samples were incubated for $10 \mathrm{~min}$ on ice. Next, $10 \mu \mathrm{l}$ or $4 \mu \mathrm{l}$ of a mix containing $20 \mathrm{mM}$ ATP, $10 \mathrm{mM}$ magnesium chloride, $14 \%$ (v/v) PEG and $200 \mathrm{mM}$ phosphate buffer, $\mathrm{pH} 7.3$, was added and samples were incubated for an additional hour at $23^{\circ} \mathrm{C}$. The assay with native $\mathrm{C}$ complex proteins (Fig. 2) was performed using $\mathrm{B}^{\text {act } \Delta \text { prp2 }}$ spliceosomes (1.2 fmol, $0.03 \mathrm{nM}$ ) and $\mathrm{C}$ complex proteins ( $16 \mathrm{fmol}, 0.4 \mathrm{nM}$ ) in a final volume of $40 \mu \mathrm{l}$. Samples supplemented with MN-digested extract contained $40 \%(\mathrm{v} / \mathrm{v})$ of it. After the splicing reaction, samples were treated with proteinase $\mathrm{K}$, mixed with 100-150 $\mu \mathrm{l}$ $0.3 \mathrm{M}$ sodium acetate, $\mathrm{pH} 5.2$, extracted with phenol-chloroform and precipitated with 3-4 volumes of ethanol. RNAs were separated by electrophoresis on $8 \%$ polyacrylamide gels (29:1 polyacrylamide/bisacrylamide) containing $8 \mathrm{M}$ urea and exposed to a Phosphorimager screen (Amersham).

Rearrangement of the $\mathrm{B}^{\text {act }} \Delta \mathrm{prp}^{2}$ spliceosome. Affinity-purified $\mathrm{B}^{\text {act }} \Delta$ prp2 spliceosomes (final concentration 3-5 nM) were incubated with RNAsin $\left(0.1 \mathrm{U}^{-1}\right)$ and proteins (150-170 $\left.\mathrm{nM}\right)$. After $10 \mathrm{~min}$ incubation on ice, ATP or AMP-PNP was added to a final concentration of $1 \mathrm{mM}$. The reactions were incubated at $23^{\circ} \mathrm{C}$ for $30 \mathrm{~min}$, then sedimented on $10-30 \%$ (v/v) glycerol gradient for $2 \mathrm{~h}$ at 490,000 $\mathrm{g}$ in a TH660 rotor (Sorvall). Gradient buffers contained 75 or $500 \mathrm{mM}$ potassium chloride. RNA from four peak fractions were recovered, separated by denaturing PAGE and visualized by autoradiography. Four fractions of each peak were pooled and proteins were precipitated with 2 volumes of ethanol in $30 \mathrm{mM}$ sodium acetate, $\mathrm{pH}$ 5.2, separated by SDS-PAGE and analyzed by MS.

Northern blotting. For northern blots, RNA was separated by electrophoresis on an $8 \%$ polyacrylamide gel containing $8 \mathrm{M}$ urea, transferred to nylon membrane (Amersham) and fixed by UV irradiation. Probes of the full-length yeast genes coding for U1, U2, U4, U5 and U6 snRNAs were made by the random priming method with the Prime-It kit (Stratagene). Hybridization and washing of blots were as previously described ${ }^{39}$.

Electron microscopy. Purified $\mathrm{B}^{\text {act }} \Delta \mathrm{prp}^{2}$ spliceosomes were separated on a glycerol gradient containing $75 \mathrm{mM}$ potassium chloride after incubation with Prp $2 / \mathrm{Spp} 2$ (45S B $\mathrm{B}^{\text {act }}$ ) or Prp2/Spp $2 /$ ATP $\left(40 \mathrm{~S} \mathrm{~B}^{\star}\right)$ and fixed by adding $0.1 \%$ glutaraldehyde in the $30 \%(\mathrm{v} / \mathrm{v})$ gradient solution according to the GraFix ${ }^{40}$ protocol. Spliceosomes were adsorbed to carbon film for $2 \mathrm{~h}$ and subsequently negatively stained by uranyl formate. Images were recorded at room temperature $\left(20-25^{\circ} \mathrm{C}\right)$ under low-dose conditions on a Philips CM200 FEG electron microscope. About 7,000 particle images of spliceosomes, before and after catalytic activation, respectively, were collected. After several rounds of image alignment ${ }^{33}$ and classification ${ }^{34}$, stable class averages were obtained.

Mass spectrometry. Fractions recovered from MS2 affinity-selected complexes were pooled, precipitated with 2 volumes of ethanol and separated on 4-12\% bis-Tris- $\mathrm{HCl}$ (pH 7.0) NUPAGE polyacrylamide gels (Invitrogen) and stained with G-colloidal Coomassie Brilliant Blue. An entire lane of the Coomassiestained gel was cut into 23 slices and proteins were digested in-gel with trypsin and extracted as described ${ }^{41}$. The peptides extracted from the samples were analyzed in an LC-coupled ESI Q-ToF (Q-ToF Ultima, Waters) and/or OrbitrapXL (Thermo Fisher Scientific) mass spectrometer as previously described ${ }^{22,42}$. Proteins were identified by searching fragment spectra of sequenced peptides against the NCBI nonredundant database using the search engine Mascot.

Primer extension. For branch-site mapping, primer extension was carried out using $250 \mathrm{fmol}(150,000 \mathrm{cpm})$ of a primer $5^{\prime}$-TATAATATAGCAACAAAAAG-3' ${ }^{32} \mathrm{P}$-labeled at the $5^{\prime}$ end, 40 fmol of PAGE-purified intron- $3^{\prime}$ exon intermediate and 1.5 U AMV reverse transcriptase (USB) in $5 \mu$ l volume. The RNA and primer were first boiled for $1 \mathrm{~min}$, then cooled at room temperature for $\sim 10 \mathrm{~min}$ before addition of the enzyme and nucleotides at a final concentration of $0.1 \mathrm{mM}$. The extension was carried out at $39^{\circ} \mathrm{C}$ for $2 \mathrm{~h}$. Reactions for sequencing lanes contained $500 \mathrm{fmol}$ yeast actin pre-mRNA and $60 \mu \mathrm{M}$ dideoxyribonucleosidetriphosphate (ddNTP) as required. The reactions were mixed with a formamide loading dye and resolved on $9.6 \%$ polyacrylamide (37.5:1 polyacrylamide/ bisacrylamide)/8 $\mathrm{M}$ urea gel.

Cloning and expression strategy. The full-length PRP2, PRP16, CWC25, CWC23, PRP22, SLU7 and PRP18 genes, and the N-terminally truncated form of SPP2 (coding for amino acids 36-185), were PCR-amplified from genomic DNA of S. cerevisiae (strain W303A) and ligated into the following vectors: PRP2 and SPP2 into pET21a (Novagen); PRP16 and PRP22 into pET22b (Novagen), thus fusing the proteins to a C-terminal hexahistidine tag; CWC25 and PRP18 into pETM11 (http://www.embl.de/ExternalInfo/ protein_unit/draft_frames/frame_which_vector_ext.htm), generating fusion proteins with an $\mathrm{N}$-terminal hexahistidine tag, cleavable with a tobacco etch virus (TEV) protease; and CWC23 and SLU7 into pGEX6P1 (GE Healthcare), producing an N-terminal fusion with glutathione-S-transferase (GST), with a PreScission protease recognition site for cleaving the protein from GST. The constructs were transformed into Escherichia coli strain Rossetta II (Novagen). Cultures were grown in 6 liters of $2 \times$ YT medium and induced with $0.6 \mathrm{mM}$ IPTG (hexahistidine-tagged) or $0.1 \mathrm{mM}$ IPTG (GST-tagged proteins) or in 1 liter of auto-inducing medium ${ }^{43}$. Cultures were incubated at $17^{\circ} \mathrm{C}$ for 20 or $48 \mathrm{~h}$, respectively. Cells were harvested by centrifugation at $5,500 \mathrm{~g}$ for $30 \mathrm{~min}$, washed and the pellets stored at $-80^{\circ} \mathrm{C}$. Purification of recombinant proteins is described in Supplementary Methods.

38. Yean, S.L. \& Lin, R.J. U4 small nuclear RNA dissociates from a yeast spliceosome and does not participate in the subsequent splicing reaction. Mol. Cell. Biol. 11, 5571-5577 (1991).

39. Fabrizio, P., McPheeters, D.S. \& Abelson, J. In vitro assembly of yeast U6 snRNP: a functional assay. Genes Dev. 3, 2137-2150 (1989).

40. Kastner, B. et al. GraFix: sample preparation for single-particle electron cryomicroscopy. Nat. Methods 5, 53-55 (2008).

41. Shevchenko, A., Wilm, M., Vorm, O. \& Mann, M. Mass spectrometric sequencing of proteins silver-stained polyacrylamide gels. Anal. Chem. 68, 850-858 (1996).

42. Hu, Q. et al. The Orbitrap: a new mass spectrometer. J. Mass Spectrom. 40, 430-443 (2005).

43. Studier, F.W. Protein production by auto-induction in high-density shaking cultures. Protein Expr. Purif. 41, 207-234 (2005). 